\title{
Tasawuf dalam Cengkeraman Materialisme Historis: Kajian Pemikiran Husein Muruwwa
}

\author{
Abdul Kadir Riyadi \\ Universitas Islam Negeri (UIN) Sunan Ampel Surabaya, Indonesia \\ e-mail: riyadi.abdulkadir@gmail.com
}

\begin{abstract}
By referring to the thought of Husain Muruwwa, this study looks at the spiritual dimension of Islam, namely Tasawuf, and how it is being interpreted in terms of a continuous social change. Muruwwa -the paper tries to show- is confident that the only authentic approach to interpret Islam and Tasawuf in terms of social change is historical materialism, which he often calls intellectual Marxism or Realist Socialism. The advantage of this approach, he argues, lies in its ability to rejuvenate the missing intellectual dimension of Islam, but also in its capacity to produce knowledge as well as in establishing the link between the past and the present. The whole idea of the link between the pastand the present is associated with his project to formulate what he calls, a new national culture. While believing that Islam can be a vibrant source of the new culture, he treats this religion as a form of culture as such. Hence -this paper shows- Muruwwa's notion of Islam is quite heterodox since he tries to drag out its theological dimension in order to dig up its social aspects. His view of Tasawuf is egually uncommon. His is the idea that Tasawuf has nothing to do with Islam. It is rather the product of social interaction in a particular society. Being Marxist moreover, he maintains that the central teaching of the Sufis is not to encourage men to know God, but to become God as such.
\end{abstract}

Keywords: Historical Materialism, Realist Socialism; Tasawuf.

\section{Pendahuluan}

Perubahan sosial selalu membawa tantangan yang tidak mudah untuk dihadapi. Semakin cepat sebuah perubahan, semakin berat pula tantangan yang ia hadirkan. Namun menyesuaiakan diri dengan kondisi baru dengan segala konsekuensi yang dihadapi adalah keniscayaan yang harus dilakukan, tak terkecuali oleh agama.

Melebihi zaman manapun dan era kapanpun, masa sekarang adalah masa paling menantang dalam sejarah ummat manusia. Betapa tidak, segalanya telah berubah dalam hitungan yang sangat cepat. Dan perubahan yang terjadi, menyentuh sendi-sendi kehidupan yang paling inti dan mendasar. Tidak ada 
manusia yang tidak tersentuh oleh arus perubahan ini. Mereka yang tinggal di ujung dunia paling pelosok pun ikut merasakan dampaknya.

Perubahan yang terjadi masa kini ditandai antara lain dengan kemajuan ilmu pengetahuan dan produk teknologi yang dihasilkannya. Beberapa dekade lalu, perubahan yang ada lebih menyentuh pada tataran sosial dan budaya bukan ilmu pengetahuan- dan ditandai antara lain dengan pertarungan ideologi antara kamp kapitalis dan komunis. Walau bentuknya beda, namun hakekat perubahan dulu dan sekarang -dan juga nanti- tetap sama karena sama-sama menghadirkan unsur baru dan menuntut pergantian atas unsur lama. Satu ciri yang paling menonjol dalam setiap proses ini adalah adanya pertarungan antara -setidaknya- dua kekuatan yang saling bersaing yaitu sosialisme dan kapitalisme, atau sosialisme dan agama, atau kapitalisme dan agama terutama Islam. Belakangan ini dalam beberapa saluran TV dunia, dan pusat-pusat kajian yang kredibel sering dibahas mengenai pertarungan antara Islam dan kapitalisme.

Sebelumnya, pertarungan antara Islam dan sosialisme lebih sering menjadi perbincangan terutama di kawasan Timur Tengah. Walau sudah usang, namun realita ini sudah terlanjur menjadi sejarah sehingga tidak saja layak untuk dikaji namun juga wajib diungkap agar diketahui oleh generasi sekarang. Masa kini tidak dapat dibangun tanpa memahami hakekat masa lalu, sebagaimana masa depan tidak dapat dipersiapkan tanpa membangun masa kini.

Salah satu sosok yang menjadi pelaku pertarungan antara Islam dan sosialisme sekaligus representasi dari proses itu adalah Husein Muruwwa, pemikir asal Lebanon yang menjadi fokus kajian ini. Ia hidup pada masa-masa kritis dan mewakili sebuah generasi yang menghabiskan sebagian besar waktunya untuk "menafsirkan ulang" Islam agar sejalan dengan semangat perubahan zaman. Dengan membahas pemikirannya, kajian ini bermaksud memberikan gambaran tidak saja tentang sosok Muruwwa namun juga tentang dinamika yang pernah dilalui Islam pada fase tertentu, dan bagaimana agama ini dinegosiasikan -atau bahkan dibenturkan- dengan realita sosial paling pelik.

Muruwwa sendiri bukan sosok yang datar. Ia penuh dengan kontroversi. Kajian ini tidak bermaksud membanggakan kontroversinya. Seperti pengikut ideologi Marxisme padaumumnya, ia mengusung gagasan revolusi dan seringkali mengesampingkan agama sebagai sistem sosial alternatif. Dalam benaknya, ada yang salah dengan sejarah Islam -bahkan dengan Islam itu sendiri- atau dengan 
cara kita membacanya. Karena itu, ia menawarkan cara baca baru yang ia klaim dapat mengurangi jarak antara idealisme Islam dengan realita sosial.

Kendati kajian ini terkesan melebar, namun sesungguhnya fokus yang diinginkan adalah pandangan Muruwwa tentang tasawuf dan bagaimana ia menafsirkannya dari sudut pandang barunya yang kadang ia sebut materialisme historis, materialisme ilmiah, atau realisme sosialis. Dengan pendekatan baru ini ia berusaha mengungkap dimensi sosial dan kultural dalam tasawuf, dan menyajikan temuan atau premis yang seringkali mengejutkan.

\section{Biografi Singkat Sang Mujtahid Merah}

Hussain Muruwwa (1910-1987) lahir di sebuah desa bernama Haddatha di wilayah Jabal Amil di Lebanon bagian selatan. Jabal Amil sendiri merupakan wilayah yang sangat dinamis dan progressif. Di sini lahir dan berkembang banyak tokoh yang ikut mewarnai sejarah dan perkembangan pemikiran Arab-Islam kontemporer. Di sini pula sering digagas sebuah aliran atau pergerakan yang dampaknya dapat dirasakan tidak saja di Lebanon namun juga di wialayah Arab dan Timur Tengah. Gagasan pembaharuan (nahdah) sering lahir dari wilayah ini. ${ }^{1}$

Pada masa kecilnya, Muruwwa tumbuh sebagai anak yang sehat dan penuh gairah. Impiannya sangat tinggi, ingin menjadi seorang ulama yang menguasai ilmu-ilmu keislaman. Walau lahir dari keluarga tidak mampu, semangat belajarnya tidak pernah surut. Pengaruh ayahnya -Ali Muruwwa-yang merupakan seorang pemuka agama, sangat besar dalam membentuk karakter dan pemikiraannya. Ia belajar ilmu agama sejak usia 8 tahun di bawah bimbingannya dan juga ulama di sekitarnya. Sebagai simbol dari keinginannya untuk menjadi ulama, sejak kecil ia sudah gemar mengenakan pakaian khas ulama seperti sorban dan jubah. Dalam autobiografinya, ia menulis, "mimpiku sejak kecil adalah menjadi ulama. Ini juga mimpi ayahku, ibuku dan keluarga besarku".2

1Lihat Tamara Chalabi. 2006. The Shi'is of Jabal Amil and the New Lebanon: Community and Nation-State, 1918-1943 (New York: Palgrave MacMillan). Lihat Fruma Zachs. "Cultural and Conceptual Contributions of Beiruti Merchants to the Nahda". Dalam Journal of the Economic and Social History of the Orient. 55 (2012), 153-182

3. June

2 Husain Muruwwa. 1984. "Min Najaf Dakhala Hayati Marx". Dalam al-Tariq. 42: 2-

JURNAL THEOLOGIA - Volume 31, Nomor 2, Desember 2020 
Keluarga besarnya -seperti umumnya keluarga agamawan di wilayah Jabal Amil- adalah pengikut aliran Shi'ah. Hubungan wilayah ini dengan pusatpusat kajian Shi'ah di Irak dan Iran sangatlah dekat. Secara ideologis dan emosional, wilayah ini lebih dekat dengan Najaf dan Qum dari pada Kairo atau Mekkah. Sejak tahun 1909, menjelang kelahiran Muruwwa, di wilayah ini telah lahir gagasan pembaharuan yang digawangi oleh para pemuka aliran Shi'ah di sana.

Pada usia 14 tahun, Muruwwa memutuskan pergi ke Najaf untuk mendalami ilmu agama terutama tafsir, fikih dan bahasa Arab. Di sana, ia belajar bersama para murid yang di kemudian hari menjadi pemuka agama yang disegani, antara lain Muhammad Salih Bahrul Ulum, Hashim al-Amin, Muhammad Jawad Mughniyyah, Ali Zain, Muhammad Shararah, Salih Ja'fari, Ali al-Sharqi, dan Muhammad Ali Khumaini. Salah satu teman se-kelasnya yang menonjol dan layak disebut secara khusus dalam konteks pemikiran revolusioner adalah Muhsin Shararah. Sosok ini gemar membahas masalah "keterbelakangan, kejumudan, dan kepalsuan para ulama". ${ }^{3}$

Seperti Shararah, Muruwwa juga gemar dengan gagasan revolusioner. Ia merasa jengah dengan kejumudan para ulama tradisional. Pada usia yang masih muda, ia teriak kencang "menghujat" kekolotan mereka. Di kota ini, di samping belajar ilmu agama ia juga menghabiskan banyak waktunya mengikuti perdebatan mengenai isu-isu kekinian, dan terlibat dalam diskusi-diskusi kecil mengenai gagasan para tokoh pemikir di dunia Arab-Islam. Di antara tokoh yang pemikirannya ia gemari adalah Thaha Hussein, Shibli al-Shumayyil dan Farah Antun. Selama di Najaf, ia tidak saja mendalami paham-paham itu namun juga menghayatinya pada usia yang belum genap 20 tahun. Gagasan pembaharuan Islam yang bermunculan pada awal hingga separo pertama abad 20, ia gemari karena berdekatan secara epistemologi dengan semangat revolusioner. Bahkan dalam perkembangannya nanti, ketika ia sudah mencapai kematangan intelektualnya, ia menganggap pemikiran Islam sebagai, "bagian alamiah dari materialisme historis". ${ }^{4}$

Di Najaf ia mengaku menemukan Marxisme, walau belum mengadopsinya secara total. Di kota inilah -dalam ungkapannya sendiri- "Marxisme masuk dalam

${ }^{3}$ Lihat Werner Ende. 1997. "From Revolt to Resignation: The Life of Mushin Shararah". Dalam Humanism, Culture and Language in the Near East: Studies in Honor of Georg Krotkoff. Editor Asma Asfaruddin dan Mathias Zahniser (Winona Lake: Eisenbrauns).

${ }^{4}$ Hussain Muruwwa, dkk. 1987. Dirasat fi al-Islam (Beirut: al-Farabi), 39-101 
hidupku". ${ }^{5}$ Namun sebagai sosok muda yang masih labil, pada fase ini ia masih sering mencari alternatif lain yang bisa jadi lebih baik dari ideologi ini. Walau demikian, dapat dipastikan bahwa begitu besarnya pengaruh Marxisme sehingga pada tahap ini ia sudah mulai ragu dengan kebenaran agamanya -bukan sebagai sistem keyakinan- namun sebagai sistem sosial yang memiliki faktor pembeda.

Didorong semangat revolusi ala Marx, ia aktif melancarkan kritiknya terhadap beberapa institusi agama seperti Hauzah, yaitu sistem pengajaran tradisional Shi'ah terutama di Najaf dan Qom. Gagasan dan pemikirannya ia tuangkan dalam dua jurnal yang berafiliasi dengan Shiah modernist yaitu al-Ifran dan al-Hatif. Menurutnya, Hauzah harus bertanggungjawab atas kemunduran dan kejumudan pemikiran Islam. Ia merasa para ulama tradisional hanya menjual mimpi dan janji palsu. Ia menulis, "kami tidak puas dengan kondisi pendidikan dan moralitas Najaf. Maka kami ingin mengutarakan kekecewaan kami baik secara pribadi maupun di hadapan khalayak. Kami tahu bahwa para pemuka agama di Najaf tidak akan mau mendengar kami dan justru akan menyalahkan kami telah membuat keonaran".6

Pada tahun 1925 ketika masih berada di Najaf, ia bergabung dengan gerakan al-Shabibah al-Amiliyyah al-Najafiyah (Gerakan Pemuda Amiliya-Najaf) yang menggaungkan semangat revolusi untuk mendobrak apa yang mereka sebut sebagai "otoritas ulama jumud nan otoriter".7 Tergabung dalam gerakan ini antara lain adalah Muhsin Shararah, teman sekelasnya.

Entah alasan apa, ia segera meninggalkan Najaf yang tentunya secara tradisional dan emosional dekat dengan dirinya, menuju Baghdad pada tahun 1927. Di banding Najaf, Baghdad masih relatif sepi dari gaung revolusi. Namun di sana sudah ada bibit-bibit pemberontakan terhadap pemerintah yang berkuasa, yaitu rezim Kerajaan Hashimi. Itu adalah lahan subur bagi tumbuh kembangnya paham Marxisme. Ia pun ke sana tentunya bukan untuk mencari "al-Ghazali" atau mengaji kepada para sufi, melainkan untuk berguru kepada "Karl Marx". Marxisme sendiri sudah lahir di Baghdad pada tahun 1924, atau tiga tahun sebelum kedatangannya. Persisnya ketika seorang mahasiswa bernama Husain

5 Husain Muruwwa. 1997. "Min Najaf Dakhala Hayati Marx". Dalam Husain Muruwwa Fi Masiratihi al-Nidhaliyyah Fikran wa Mumarasatan. Editor al-Majlis al-Thaqafi li Lubnan al-Janub (Beirut: Dar al-Farabi), 89

${ }^{6}$ Majallah Al-Ifran. Nopember 1928, 411

${ }^{7}$ Chalabi. The Shi' is of Jabal Amil, 97 
Rahhal membentuk organisasi mahasiswa berhaluan kiri bernama Nadi alTadhamun disusul dengan diterbitkannya buletin al-Sahifah yang memuat gagasan revolusioner ala Marx. Dengan cepat Marxisme menjadi idola, dan pada tahun 1927 sudah mampu menjadi motor penggerak gerakan mahasiswa dalam menentang kebijakan pemerintah Kerajaan Hashimi di berbagai bidang.

Kerajaan Hashimi sudah mulai kehilangan legitimasinya karena kebijakannya yang dinilai mengkhianati amanat rakyat. Kerajaan ini tidak saja tunduk pada otoritas Inggris namun juga terkesan mendukung kepentingan mereka. Inggris sendiri sejak menduduki Irak pada tahun 1920 setelah mengikis pengaruh Khilafah Usmaniyah, senantiasa membuat kebijakan yang merugikan rakyat. Tercatat pendidikan bagi pribumi terabaikan, hak kaum buruh dinafikan, kondisi kaum petani memprihatinkan, monopoli merajalela, pajak progresif menguras harta, rakyat sipil diintimidasi, militer selalau mengawasi, sentimen etnisitas menguat, dan undang-undang dibuat hanya untuk melindungi mereka yang berkuasa dan kuat. Puncaknya selama perang dunia II, Irak mengalami inflasi sebesar 500\%, dan 50\% penurunan daya beli masyarakat. Kondisi ekonomi memburuk, pengangguran di mana-mana. Kaum muda merana, kaum tua semakin renta. Kondisi itu diperburuk dengan adanya kesepakatan dagang antara Kerajaan dan otoritas Inggris pada tahun 1948 bahwa bangsa kolonial berkuasa penuh atas bumi Irak.

Bagi siapapun kondisi ini terlalu buruk untuk dihadapi. Dan ironisnya, hanya kaum komunis -menurut pengakuan Muruwwa- yang rela berjuang menentang ketidakadilan itu. ${ }^{8}$ Serangkaian demo anti Kerajaan yang mereka gelar memakan korban ratusan orang meninggal dunia. Kondisi politik yang tidak kunjung membaik memaksa Muruwwa kembali ke Lebanon pada tahun 1950. Di tengah nasib rakyat yang tidak menentu, ia mempertanyakan di mana peran agama dan ulama? Mengapa mereka diam dan tidak angkat bicara? Untuk yang ke sekian kali, ia ragu dengan peran agama dalam kehidupan nyata.

Selama berada di Irak, Husain Muhammad al-Shabibi paling berperan menanamkan bibit-bibit keraguan terhadap agama. Menariknya, al-Shabibi adalah seorang Mullah dan salah satu pendiri Partai Komunis Irak (ICP). Dia

8Mengenai sejarah Iraq secara umum pada masa ini, lihat Liora Lukitz. 1996. Iraq: The Search for National Identity (London: Frank Cass). Adapun terkait dengan perlawanan kaum komunis dan sosialis kepada Kerajaan Hashimi secara khusus lihat Madjid Khaduri. 1978. Socialist Iraqi: Study in Iraqi Politics Since 1968 (London: Middle East Institute), 160 
meyakinkan kepada Muruwwa bahwa Komunisme tak tergantikan. Di tangannya, Muruwwa benar-benar dibaiat menjadi pengikut sekaligus ideolog Marxisme yang sesungguhnya. Al-Shabibi memberinya pemahaman yang memuaskan tentang hakekat Komunisme, beberapa aliran dan ajarannya, dan meyakinannya bahwa Communist Manifesto dan Capital karya Marx, dan State and Revolution karya Lenin adalah kitab suci perjuangan yang tiada duanya.

Kontribusi intelektual Muruwwa sebagai seorang komunis selama di Irak diakui secara luas oleh koleganya. Ia pun dijuluki "mujtahid merah" pada tahun 1938 sebagai bentuk apresiasi akan penguasaannya yang mendalam terhadap khazanah pemikiran Islam pada satu sisi, dan kesetiannya pada ideologi Komunisme-Marxisme pada sisi lain. ${ }^{9}$ Di kalangan Shi'ah, ia benar-benar dianggap sebagai ulama yang mumpuni, dan di kalangan pengikut Komunisme dipuja sebagai imam mereka.

Setelah fase Irak, ia menjalani masa-masa yang relatif lebih indah di Lebanon sebelum terjadinya perang saudara yang mengerikan di negeri itu pada tahun 1975-1990. Setibanya di Lebanon ia bergabung dengan Lebanese Communist Party (LCP) pada tahun 1954. Kegiatan tulis menulis ia jalani dengan dengan intensitas yang lebih tinggi. Perjuangannya masih tetap sama, mengusahakan kehidupan sosial yang lebih adil dengan kendaraan KomunismeMarxisme dan dengan pendekatan politik-intelektual. Gagasan dan pemikirannya pada fase ini ia tuangkan dalam beberapa karya antara lain Qadhaya Adabiyah (Isu-isu Kesusastraan) yang terbit pada tahun 1956.10 Karya ini menandai perhatiannya kepada dunia sastra Arab kontemporer sebagai entry untuk menyuarakan kepeduliannya kepada dunia sosial dan politik. Melalui karya ini ia mencoba menyampaikan kritiknya kepada para pemikir kontemporer yang menyalahgunakan sastra secara khusus dan wacana keagamaan secara umum untuk kepentingan kelompok atau pribadi. Dalam penilaiannya, kebanyakan intelektual "memiliki kepentingan dan ditunggangi oleh sebuah kepentingan".11

Kritiknya terhadap kesusastraan Arab kontemporer juga sejatinya merupakan bentuk kekecewaannya atas sikap Thaha Husein dan Ra'if Khuri.

9Louis Allday. "Rembering Hussayn Muruwwa: The Red Mujtahid". Dalam Jadaliyah, 17/2/2017.

${ }^{10}$ Lebih jauh tentang karya ini, lihat Husain Muruwwa. 1965. Qadaya Adabiyyah (Kairo: Dar al-Fikr).

11 Ibid., 45 
Keduanya sering berdebat namun tidak pernah menyentuh persoalan akar rumput. Pandangan mereka "jauh panggang dari api". Para sastrawan Arab lainnya seperti Taufiq al-Hakim dan Abbas Aqqad tidak luput dari kritiknya. Pandangan mereka yang mengatakan bahwa "politik merusaksastra" ia tolak dan ia tawarkan pandangan sebaliknya bahwa "politik menyuburkan dan memupuk sastra". ${ }^{12}$

Keterlibatannya dalam "perang para sastrawan" menunjukkan kepeduliannya yang mendalam tentang kondisi sosial, politik dan keagamaan masyarakatnya. Selain melalui buku, ia juga rajin menyampaikan gagasannnya lewat media massa seperti harian al-Hayat yang berhaluan kiri, surat kabar mingguan al-Thaqafah al-Wataniyyah yang ia dirikan sendiri bersama dua tokoh komunis Lebanon, Niqola Shawi dan Farjullah al-Hilw.

Pada tahun 1966, ia berkesempatan mengunjungi Moscow. Ini adalah kunjungan keduanya setelah sebelumnya pernah ke sana pada tahun 1954 yang kala itu sebagai perwakilan kaum komunis Lebanon dalam acara Kongres Kedua Pujangga Soviet. Dalam kunjungan keduanya ini ia menetap selama setahun penuh dan menggali ajaran Komunisme dari sumbernya. Ini adalah waktu terbaiknya sepanjang hidupnya. Ia sering merindukan momen ini. Baginya Uni Soviet adalah "tanah suci", pemimpinnya adalah pandito, tentaranya para jawara, dan Kremlin adalah kiblat yang sakral.13 Yang lebih penting dari itu, Moscow menyediakan segala yang ia butuhkan untuk menyelesaikan karya yang merupakan magnum opusnya berjudul al-Naza'at al-Madiyyah fi al-Falsafah alArabiyah al-Islamiyah (Kecenderungan Materialistik dalam Filsafat Arab-Islam). Karya ini -terlepas dari kontroversinya- memberikan sudut pandang yang unik mengenai khazanah pemikiran Islam, dan masih merupakan -menurut Yoav di Capua- karya terbaik yang pernah ditulis mengenai hubungan antara wacana pemikiran Arab-Islam klasik dengan budaya Arab kontemporer. ${ }^{14}$

Hubungan emosionalnya dengan Moscowyang lebih kuat dari pada ikatan spiritualnya dengan Mecca membuat pertanyaan mengenai agamanya muncul. Apakah ia masih seorang Muslim? Pertanyaan ini memang tidak terlalu relefan

\footnotetext{
12 Ibid.,

13 Ini adalah ungkapan hatinya yang ia sampaiakan saat kunjungan pertamanya. Lihat Muruwwa. Qadaya, 66-67

14 Yoav Di-Capua. 2013. "Homeward Bound: Husayn Muruwwah's Integrative Quest for Authenticity”. Dalam Jounral of Arabic Literature. I January, Vol 44, Issue 1, 23, 47
} 
dalam kajian akademik. Agama adalah urusan pribadi seseorang. Namun kenyataannya, banyak yang mempersoalkannya mungkin karena melihat latar belakangnya sebagai seorang shaikh yang disegani.

Abbas Baidun yang menulis biografinya meyakini bahwa Muruwwa bukan saja seorang Muslim tapi juga "penjaga gawang akidah Islam".15 Tidak terlalu jelas apa yang ia maksudkan dengan ungkapan ini dan apa pula makna "akidah Islam" bagi seorang Marxist seperti Baidun. Muruwwa sendiri nampaknya tidakterlalu peduli dengan pengertian akidah Islam. Pemahamannya tentang Islam sangatlah longgar. Dalam sebuah kesempatan ia bahkan memaknai Islam sebagai agama perubahan lewat revolusi. ${ }^{16}$

Berbeda dengan Baidun, Miriam Younes justru menganggapnya telah meninggalkan nilai-nilai agama Islam yang pernah dianutnya. Penilaian ini mendapat dukungan dari Yoav Di-Capua. Dengan nada yang lebih diplomatis, DiCapua berpandangan bahwa Muruwwa hanya sebatas "bangga terhadap warisan pemikiran Islam". ${ }^{17}$ Secara ideologis ia adalah seorang Marxis dan karenanya lebih terpanggil untuk "memperjuangkan nasib rakyat yang tertindas" dengan menggunakan ideologi Marxisme ketimbang bicara soal agama. Di-Capua melanjutkan bahwa, "sejarah hidup berikut proyek pemikirannya menunjukan bahwa baginya agama telah usang". 18

Sejalan dengan itu tanpa menyebutkan identitas keagamaannya, Fahmi Jad'an meyakini tanpa ragu bahwa Muruwwa adalah seorang Marxis. Dan sebagai penganut ideologi ini, Muruwwa "telah membawa pengalaman pahit bagi khazanah pemikiran Islam. Namun usahanya menafsirkannya layak dihargai”. ${ }^{19}$

Sementara itu, bagi Louis Allday, Muruwwa adalah seorang Muslim sekaligus komunis. ${ }^{20}$ Perjuangannya sejalan dengan ideologi Marxisme, namun gaya hidupnya lebih selaras dengan nilai dan budaya Islam yang diwarisinya dari kedua orang tuanya. Ayahnya memberikan pengaruh yang kuat dalam dirinya dan meninggalkan kesan mendalam tentang gaya hidup Islami. Allday

${ }^{15}$ Hussain Muruwwa. 1990. Wulidtu Shaikhan wa Amutu Tiflan. Editor Abbas Baidun (lebanon: Dar al-Farabi), 5

${ }^{16}$ Muruwwa. Dirasat fi al-Islam, 1-35

${ }^{17}$ Di-Capua. Ibid, 37

18 Ibid., 52

${ }^{19} \mathrm{Fahmi} \mathrm{Jad'an.} \mathrm{2017.} \mathrm{"Pengantar".} \mathrm{Dalam} \mathrm{al-Turath} \mathrm{al-Arabi} \mathrm{wa} \mathrm{al-'Aql} \mathrm{al-}$ Madi:Qira'ah fi Fikr Hussain Muruwwa (Beirut: Dar al-Tanwir), 10

${ }^{20}$ Allday. Ibid 
menekankan bahwa Muruwwa "lahir sebagai seorang Shaikh", untuk menegaskan komitmen keagamaannya, namun ia juga pengikut ideologi "merah" untuk menekankan identitas komunisnya.

Pembahasan mengenai identitas keagamaan Muruwwa tetap menarik, namun di luar jangkauan tulisan ini. Yang pasti, fenomena konversi pemikiran bahkan keyakinan di wilayah Timur Tengah di kalangan tokoh pemikir telah menjadi perbincangan banyak orang. Betapa tidak di tengah pertarungan ideologi yang sangat keras, ternyata arus kepindahan tokoh pemikir ke markas rival sering terjadi. Seorang cinemanologi bernama Laura U Marks pernah coba memotret fenomena ini pada tahun 2015 melalui novel ilmiahnya berjudul Hanan al-Cinema. ${ }^{21}$

Muruwwa sendiri termasuk golongan Islam yang loncat ke aliran Marxisme karena terpukau dengan ideologi pembebasannya. Sebelum menemukan Marxisme, ia sempat menyelami berbagai pola dan aliran pemikiran sosial keagamaan. Ia menggemari Thaha Hussein yang mengusung Liberalisme dan Shibli al-Shumayyil yang membawa gagasan Ateisme dan Darwinisme.22 Pembacaannya atas Thaha Hussein juga mengajarinya tentang kritik satra moderen. Jamaluddin al-Afghani, Muhammad Abduh dan Abdul Rahman alKawakibi memberinya gambaran tentang pemikiran Islam kontemporer dan gagasan pembaharuan. Di bidang sejarah, ia sangat kagum pada Ahmad Amin.23 Di bidang politik, ia menggemari Ahmad Lutfi al-Sayyid yang memberinya pemahaman mengenai modernitas dan liberalisme politik. Ismail Mazhar bersama Shibbli Shumayyil berkontribusi menyediakan landasan metodologis dalam pemikirannya. ${ }^{24}$ Niqula Haddad membantunya menangkap gambaran radikal mengenai realita feudal di wilayah Jabal Amil tempat kelahirannya. Namun di atas itu semua ada Husain Muhammad al-Shabibi dan Farah Antun yang paling berpengaruh membentuk jati diri dan karakter pemikirannya. Karya Antun yang berjudul Religion, Knowledge and Capital: A Story abour Conflict of Three Cities (1903) yang ia baca pertama kali pada tahun 1926 mengantarkannya menjadi seorang Marxis sejati. Buku ini bicara soal konflik kelas dan masalah

${ }^{21}$ Lihat Laura U. Marks. 2015. Hanan al-Cinema: Affections for the Moving Image (USA: MIT Press)

22 Di-Capua. Ibid, 23

${ }^{23}$ Al-Safir . 22 September, 1985 3. June 177

${ }^{24}$ Husain Muruwwa. 1984. "Min Najaf Dakhala Hayati Marx". Dalam al-Tariq. 42: 2- 
ketidakadilan. Ia belajar bahwa kehidupan masyarakat adalah tentang pertentangan dan konflik. Kelompok lemah selalu berada pada pihak yang kalah. Uang dan kekuasaan adalah sumber kekuatan, sedang agama adalah masa lalu yang usang.

Muruwwa meninggal dengan sangat tragis pada tahun 1987 dengan cara ditembak dari jarak dekat di dalam rumahnya. Walau pelakunya tidak diketahui hingga sekarang, namun pihak Partai Komunis Lebanon meyakini bahwa militia Shi'ah dan partai Harakat Amal berada di balik pembunuhan itu. ${ }^{25}$

\section{Islam sebagai Budaya Baru}

Menjadi Marxist tidak membuatnya cemas dengan stigma bahwa ideologi ini merupakan anti-tesa dari agama. Ia justru merasa bahwa keduanya dapat dikawinkan. Islam yang menurutnya terlalu idealis gagal berdialektika dengan realita sosial. Karenanya, Islam harus dibumikan dengan cara menafsirkannya dalam kerangka teori Marxist seperti Materialisme Historis, Materialisme Ilmiah dan Realisme Sosialis.

Muruwwa sendiri menerapkan tiga pendekatan itu dalam semua karyanya baik secara bergantian atau dengan cara digabungkan. Lebih jelasnya, al-Naza'at menggunakan pendekatan Materialisme Historis dan Materialisme Ilmiah, sedang semua karyanya yang lain menggunakan Realisme Sosialis.

Materialisme Historis dan Materialisme Ilmiah adalah pendekatan sekaligus ideologi bagi kaum terpinggirkan. Muruwwa merasa keduanya berguna untuk menciptakan ilmu pengetahuan baru. Dengan cara melihat fenomena sosial secara dialektis, kedua pendekatan ini meniscayakan bahwa hubungan masyarakat selalu didominasi oleh pertentangan dan konflik. Melihat budaya dan tradisi dengan menekankan pada dimensi historisnya menjadi andalam pendekatan ini.

Materialisme tidak tunggal. Ada jenis materialisme aliran para filsuf Yunani kuno, materialisme metafisis yang dianut oleh para filsuf Eropa abad 17, 18 dan awal 19 yang berangkat dari pola pikir mekanik, dan materialisme

25 Rula Jurdi Abisaab dan Malek Abisaab. 2014. The Shi'ites of Lebanon: Modernism, Communism and Hizbullah's Islamists (Syracuse: Syracuse University Press), 72 
demokratis revolusioner. Yang dianut Muruwwa dan ia anggap paling benar adalah materialisme yang dialektis. ${ }^{26}$

Sementara itu Realisme Sosialis adalah gagasan yang mendambakan masyarakat yang adil tanpa sekat, menyuarakan kesadaran kelas, mewakili budaya kelas, berpegang teguh pada kepentingan politik (Partynost) dan menyokong kepentingan dan pandangan rakyat jelata (Norodnost). ${ }^{27}$

Sebagai pendekatan, Realisme Sosialis menekankan bahwa seorang penulis adalah "sosok yang bebas" yang tidak boleh dipengaruhi oleh apapun termasuk keyakinan, norma maupun asumsi-asumsi bawaan. Ia mengasumsikan bahwa ada "kesalahan" dalam struktur dan cara berpikir manusia baik dalam bidang agama, seni, budaya, politik dan lainnya. Realisme Sosialis diciptakan untuk memperbaiki kesalahan itu. Karena terbentuk dalam konteks peperangan dan persaingan dengan Kapitalisme, pendekatan ini meniscayakan bahwa kaum hartawan adalah kelompok "jahat" sedang kaum tertindas adalah kelompok "baik". Dalam ungkapan Andrei Zhdanov, "Realisme Sosialis mengetengahkan realitas dalam bentuknya yang revolusioner". ${ }^{28}$ Revolusi yang dimaksud adalah 1) perlawanan terhadap agama dan kalangan penguasa untuk membela kaum lemah, dan 2) merubah sistem feudal yang menguntungkan kaum kaya dan menawarkan sistem sosial yang adil untuk semua.

Salah satu karyanya yang menunjukkan kepribadian Muruwwa sebagai seorang realis-sosialis adalah biografinya berjudul Wulidtu Shaikhan wa Muttu Tiflan (Saya Lahir sebagai Shaikh dan akan Mati sebagai Anak-anak). Karya ini pertama terbit pada 1990 namun sudah ditulis oleh Abbas Baidun jauh sebelum itu. Baidun menyebut Muruwwa dalam karya ini sebagai seorang pemikir dan pejuang. ${ }^{29}$ Penampilannya santun dan teduh. Ketika berbicara, ia menunjukkan semangat juang yang tiada tara. Baidun sendiri kagum kepadanya karena segala kondisi sulit yang pernah dihadapinya tidak lantas membuatnya sebagai pemarah. Baidun menulis, "tidak seperti penjaga gawang akidah pada umumnya, Muruwwa adalah sosok yang tenang dan penuh karisma". ${ }^{30}$ Semangat hidup selalu memancar dari dirinya. Usia tua tidak membuatnya mengurangi aktifitas

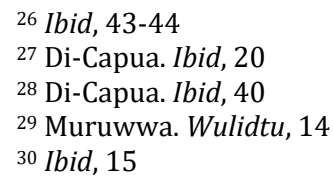


kepenulisannya. Karena itu ia "ingin mati sebagai anak-anak". Kalimat yang meyimbolkan bahwa -seperti seorang anak- ia ingin terus bahagia, riang dan gembira apapun kondisinya.

Kegembiraan pula yang memancar dari karyanya yang lain berjudul Dirasah fi al-Fikr wa al-Adab (Kajian Pemikiran dan Sastra). ${ }^{31}$ Seperti umumnya seorang sastrawan, Muruwwa selalu mengemas pemikirannya dengan gaya bahasa yang merona dan menghibur. Ia lebih menggemari sastra daripada pemikiran. Karir akademisnya juga diawali sebagai seorang sastrawan. Sastra ia gunakan sebagai alat untuk melakukan kritik sosial. Namun ia juga tidak bisa meninggalkan dunia pemikiran karena menurutnya, "kesalahan sejarah Islam terletak pada pemikirannya dan bukan pada sastranya".32 Sastra justru membawa kemajuan dan memberikan warna yang indah bagi sejarah dan peradaban Islam.

Karya lain yang lebih tegas dalam menggunakan pendekatan Realisme Sosialis adalah Dirasah Naqdiyyah fi Dhau al-Manhaj al-Waqii' (Kajian Kritis: Sebuah Metode Realisme). ${ }^{33}$ Dari judulnya saja sudah nampak metode apa yang ia gunakan. Dalam karya ini, Muruwwa melancarkan kritik kerasnya kepada kesustraan Arab. Dan dari sana mengarahkan kritik sosialnya kepada masyarakat Arab-Islam. Premis besarnya adalah bahwa keterbelakangan sastra menunjukkan keterbelakangan sosial dan budaya. ${ }^{34}$ Ia sangat menyayangkan betapa para pemuka sastra di dunia Arab, justru membunuh sastra dengan cara mengebiri budaya ekspresinya. Masyarakat Arab pada umumnya tidak memiliki budaya untuk mengekspresikan diri melalui sastra. Politik berperan besar dalam kematian sastra Arab moderen, bukan karena politik adalah musuh sastra melainkan karena sastra seringkali dipolitisir untuk kepentingan segelintir orang atau kelompok.

Terbit pertama pada tahun 1965, karya ini menyasar antara lain Taufiq alHakim terutama karena pandangannya bahwa politik tidak pernah selaras dengan sastra. ${ }^{35}$ Namun secara paradox, Muruwwa juga menyenangi sastra al-

\footnotetext{
${ }^{31}$ Mengenai karya ini lihat Hussain Muruwwa. 1993. Dirasah fi al-Fikr wa al-Adab (Beirut: Dar al-Farabi)

32 Ibid., 26

33 Mengenai karya ini lihat, Hussain Muruwwa. 1988. Dirasat Naqdiyyah fi Dhau alManhaj al-Waqi'i (Beirut: Maktabah al-Ma'arif).

${ }^{34}$ Ibid., 7

35 Ibid., 33
} 
Hakim karena sifatnya yang realis. Menurutnya, al-Hakim selalu berangkat dari kondisi masyarakat yang real. Ia gemar bicara mengenai "sesuap nasi bagi rakyat jelata", atau "perut-perut yang lapar dan mulut yang merintih". Selain al-Hakim, sastrawan seperti Mahmud Amin al-Alim dan Abdul Azim Anis juga ia gemari karena sealiran dengannya sebagai pengikut mazhab realisme sosialis.

Dua nama yang disebut terakhir ini bahkan menjalin hubungan persahabatan karib dengannya. Kedua orang ini adalah ideolog Marxisme dan kritikus sastra terkemuka asal Mesir. Aktifitas politik mereka memaksa keduanya menelan pil pahit. Mereka harus meninggalkan negaranya akibat diusir oleh Jamal Abdul Nasir setelah sebelumnya dicopot dari jabatan mereka sebagai dosen di Universitas Kairo. Mereka mengungsi ke Beirut dan bekerjasama menulis karya berjudul Fi al-Thaqafah al-Misriyyah (Budaya Mesir). ${ }^{36}$ Muruwwa bertindak sebagai pemberi pengantar dalam karya ini.

Dalam kata pengantarnya, Muruwwa mengingatkan adanya pertarungan laten antara "pemikiran lama dan baru". Pemikiran lama sudah usang sehingga harus digantikan dengan yang baru. Pemikiran lama adalah angan-angan yang tidak rasional karena tidak dibangun di atas "landasan ilmiah dan objektif". 37 Pemikiran lama melihat masa lalu sebagai jawaban atas persoalan masa kini tanpa menyadari bahwa konteks masa lalu dan masa kini sangatlah berbeda. Yang ia maksud pemikiran lama adalah yang diwakili oleh khazanah wacana Islam klasik, atau yang lebih dikenal dengan sebutan turath.

Dengan demikian dapat dipahami bahwa secara prinsip Muruwwa menolak turath bukan karena tidak berguna, melainkan karena gagal dibaca secara benar. Turath bisa saja berguna jika dibaca secara kontekstual. Inilah yang kemudian menguatkan tekadnyauntuk meluncurkan proyek besar dalam rangka menggali relevansi turath dengan usaha membangun budaya baru, atau yang sering ia sebut budaya nasional.

Turath yang mengandung pemikiran keislaman di berbagai bidang secara umum ia nilai terlalu bersifat teoretis. Para pendahulu terlalu menyibukkan diri dengan pengembangan wacana yang tercerabut dari realita sosial. Karenanya, pada masa kini turath tidak mampu menjawab persoalan zaman. Namun pada

${ }^{36}$ Lihat Mahmud Amin Alim dan Abdul Azim Anis. 1989. Fi al-Thaqafah al-Misriyah (Kairo: Dar al-Thaqafah al-Jadidah).

${ }^{37}$ Hussain Muruwwa. 1989 "Pengantar" dalam al-Alim., Ibid., 5 
sisi lain, ia juga sadar bahwa turath terlalu berharga untuk disingkirkan. Identitas kita masa kini tidak lain adalah produk dari pemikiran masa lalu. Tanpanya kita tidak mampu membaca dan membangun jati diri. Turath memiliki kandungan pemikiran yang amat berharga. Jika masa lalu yang agung dapat dibangun di atas pondasi turath, maka keagungan masa kini dan masa depan pun mestinya demikian.

Muruwwa memulai program menafsirkan ulang turath pada tahun 1952 dan berakhir pada 1968. Jurnal al-Thaqafah al-Wataniyah menjadi media paling utama dalam menyuarakan gagasannya. Ini adalah jurnal yang ia buat sendiri sebagai kendaraan perjuangannya. Sejumlah tulisan yang pernah dimuat dalam jurnal ini kemudian dibukukan dengan judul Turathuna Kaifa Na'rifuhu (Turath Kita: Bagaimana Mengetahuinya). ${ }^{38}$

Buku ini adalah gambaran bagaimana Muruwwa berpetualang dan menyelami masa lalu. Ia nampak menikmati apa yang ia sebut sebagai "usaha mencari jenis pengetahuan baru". Kepercayaan dirinya hadir dalam setiap kalimat yang ia tulis, bahwa melalui pembacaannya ini ia akan dapat "menemukan dan menghadirkan pemikiran baru yang berasal dari budaya Arab sendiri". ${ }^{39}$ Kesan bahwa ia bangga akan ke-Arabannya sangatlah kuat. Ia tidak pernah berhenti berpesan bahwa warisan pemikiran ini akan dapat membantu kita menemukan otentisitas jika "dibaca dengan cara ilmiah berdasarkan pada sudut pandang yang memperhatikan konteksnya, atau historisitasnya, atau sebagai peristiwa dalam sebuah sejarah yang terjadi pada masa tertentu dalam masyarakat tertentu". 40

Melalui kajiannya tentang turath ia mengaku banyak belajar dari para tokoh masa lalu. Walau pembacaannya subjektif dan kadang terkesan dipaksakan, ia coba menguak fakta bahwa para pendahulu memiliki kapasitas dan gagasan yang tidak pernah kita pikirkan sebelumnya. Tokoh seperti Ibn Sina umpama, ia sebut sebagai pemikir realis-sosialis yang progressif; al-Mutanabbi sebagai pejuang Arab layaknya para komrad; Abu al-A'la al-Ma'arri seorang arif yang membawa pencerahan layaknya Lenin; Ibn Muqoffa seorang nasionalis sejati; Ikhwan al-Shofa para filsut politik; Abu Hiyyan al-Tauhidi pembela kaum

38 Hussain Muruwwa. 1985. Turathuna: Kaifa Na'rifuhu (Lebanon: Mu'assasah alAbhath al-Arabiyah), 6.

${ }^{39}$ Ibid., 6.

40 Ibid., 7 
miskin layaknya Stalin; hingga al-Jahiz dan Abu Nuwas yang ia dapuk sebagai peletak dasar paham sosialisisme (al-Syu'ubiyyah).

Tapi sosialisme yang ia maksud di sini tidak sama dengan sosialisme yang berkembang di era sekarang. Setiap gagasan adalah produk zamannya. Zaman yang berbeda akan melahirkan gagasan yang berbeda pula. Sosialisme para pendahulu bukanlah ideologi atau aliran politik, melainkan kecenderungan pikir dan perilaku. Dalam konteks ini, semua sufi di masa lalu ia nobatkan sebagai sosialis karena perilaku mereka yang menunjukkan kepedulian kepada sesama.

Pengamatan Muruwwa tentang faktor di balik kemunculan "sosialisme para pendahulu" layak menjadi catatan tersendiri. Ia berpandangan bahwa sikap peduli para pendahulu tidak lahir dari agama, melainkan karena kondisi sosial dan georaphis yang mengitarinya. Agama baginya tidak memiliki peran dalam kehidupan sosial, atau dalam melahirkan sebuah aliran pemikiran dan ideologi. Sosialisme para pendahulu adalah produk ke-Araban, dan bukan keislaman.

Ini pula yang ia yakini dalam konteks kekinian atau yang terjadi di setiap zaman. Berbagai gagasan, sistem politik, budaya dan sosial kemasyarakatan yang lahir, atau ideologi yang datang silih berganti tidak ada hubungannya dengan agama. Itu semua adalah ekspresi pemikiran yang melambangkan kemanusiaan dan sisi budayanya.

Dalam narasi kalangan Islamis, sosialisme atau sistem lain seperti kapitalisme, nasionalisme dan demokrasi selalu dikaitkan dengan agama. Seolah sah untuk mengatakan sosialisme Islam, kapitalisme Islam, nasionalisme Islam atau demokrasi Islam. Bagi Muruwwa itu salah. Semua sistem itu berkaitan erat dengan sentimen seseorang dengan budayanya atau dengan kondisi zamannya, bukan dengan agamanya.

Muruwwa bahkan memandang sosialisme lebih baik dari agama sebagai sistem sosial. Agama mencerminkan budaya lama, sedang sosialisme budaya baru. Pola pikir Muruwwa yang dialektis meniscayakan bahwa agama dan sosialisme ada pada posisi saling berbenturan dan bertarung memperebutkan pengaruh. Ironisnya, agama selalu berada pada posisi kalah dan harus dikesampingkan.

Demikianlah, mengulangi apayang pernah ia katakan pada bagian awal $a l-$ Thaqafah al-Misriyyah, pada bagian akhir Turathuna Mururwwa mengingatkan akan terjadinya benturan laten antara pemikiran lama yang diwakili oleh agama 
dengan pemikiran baru yang produktif dan progresif. Yang lama harus diganti dengan cara melakukan pembacaan ulang atau menegosiasikannya dengan realita sosial yang ada. Jika itu gagal, maka terpaksa harus didongkel melalui revolusi.

Inilah yang menakutkan dari sosok Muruwwa. Turathuna dan karyakaryanya yang lain adalah ajakan revolusi untuk mengoyak tatanan lama termasuk agama dan menciptakan budaya baru, yang sering pula ia sebut budaya nasional.

Usaha membangun budaya nasional sendiri sudah ramai disuarakan di kawasan Timur Tengah sebelum Muruwwa. Di Mesir ada nama-nama seperti Muhammad Ali yang mengusung konsep nasionalisme Arab; Musthofa Abdul Raziq bicara soal nasionalisme sekuler; Salamah Musa nasionalisme rasional; Abdul Rahman Badawi nasionalisme filosofis; Husain Fauzi nasionalisme berperadaban; dan Thaha Husein nasionalisme demokratis liberal. ${ }^{41}$ Ada di antara konsep di atas yang radikal namun ada pula yang moderat. Muruwwa yang bicara dalam konteks yang lebih luas yaitu budaya Arab (tidak saja Mesir) termasuk yang radikal. Dari segi substansi pemikiran, ia dapat disejajarkan dengan Salamah Musa yang ateis atau Thaha Husein yang agnostik. Sedang dari segi pendekatan ia serupa dengan Mahmud Amin al-Alim, Abdul Azim Anis, Raif Khuri dan Umar Fakhuri.42

Semua nama yang disebut di atas -termasuk Muruwwa- memiliki persamaan yang mencolok di samping perbedaan yang tajam. Persamaannya adalah bahwa mereka semua nyaris tidak pernah bicara agama sebagai sistem sosial alternatif. Mereka lebih suka bicara budaya karena budaya lebih integratif dan akomodatif. Budaya tidak mengenal sekat dan perbedaan. Budaya memiliki sisi kemanusiaan yang tidak dapat dipecah-belah karena merupakan bangunan warisan dari masa lalu, melewati masa kini dan dapat mengantarkan manusia kepada masa mendatang. Budaya memiliki unsur estetis yang indah dan dapat melenturkan ketegangan yang tidak dimiliki oleh agama termasuk Islam.

Lalu bagaimana sejatinya orang seperti Muruwwa melihat Islam secara lebih makro dalam konteks usahanya membangun budaya nasional?

${ }^{41}$ Lihat Abdul Malik Anwar. 2006. Al-Wathaniyyah Hiya al-Hal (Kairo: Maktabah alShuruq al-Dauliyah).

42 Di-Capua. Ibid., 42 
Pandangan Muruwwa tentang Islam ia tuangkan dalam Dirasat fi al-Islam (Kajian Islam) karya yang ia garap bersama Mahmud Amin al-Alim, Muhammad Darkub dan Samir Sa'ad. Secara bergantian mereka menuangkan gagasannya dalam buku ini. Muruwwa sebagai penulis pertama. Secara garis besar, buku ini membaca Islam sebagai objek revolusi, sebuah tatanan yang harus dirombak, bukan pelaku revolusi itu sendiri.

Adakalanya Muruwwa mengakui Islam sebagai agama yang dinamis. Namun pada titik tertentu, agama ini jatuh dan tidak dapat dibangunkan keculai dengan cara radikal. Pembacaan yang salah atas Islam menjadi penyebab mengapa agama ini terpuruk. Sebagai agama besar, Islam pernah berhasil melalui perjalanan sejarah yang panjang dan dapat menjawab tantangan zaman dengan sempurna. Seiring berjalannya waktu, Islam redup. Muruwwa mengingatkan bahwa Islam memiliki segala kapasitas untuk melakukan perubahan. Namun ajarannya tidak pernah digali secara kontekstual atau realisitis.

Muruwwa juga mengakui Islam sebagai agama revolusi. Indikasinya, ia dapat bergerak menyusuri lorong-lorong sejarah. Peruabahan zaman yang sangat cepat dan tidak diantisipasi dengan baik membuatnya terbelakang. Kesadaran akan pentingnya penyegaran atas ajarannya tidak pernah dilakukan. Para ulama hanya mengulang-ulang apa yang pernah dikatakan. Sebagian dari mereka hanya menjual mimpi dan janji palsu. Semangat perubahan harus dikobarkan. Islam pernah berhasil merubah masyarakat Jahiliyah. Dan itu adalah bukti kuat bahwa ia memiliki karakter revolusioner.

Islam menolak sistem masyarakat Jahiliyah yang berbasis pada kesukuan yang primitif, kata Muruwwa. ${ }^{43}$ Ini berarti Islam anti ketidakadilan. Sistem Jahiliyah menguntungkan yang kaya dan berkuasa, merugikan yang miskin dan rakyat jelata. Bagi Muruwwa, Islam datang pada saat yang tepat dan dengan tawaran yang tepat pula.4 Menjawab kekacauan sosial yang ada, Islam menawarkan konsep Tauhid, yaitu kebersatuan teologis, sosial dan budaya. Dalam skema Tauhid, Tuhan itu tunggal, sebagaimana manusia juga selayaknya dipandang sebagai wujud yang tunggal dan bersaudara. Dalam sistem Tauhid, tidak ada orang yang lebih mulia dari yang lain kecuali dengan kadar keimanan dan ketakwaannya.

\footnotetext{
43 Muruwwa. Dirasat fi al-Islam, 9

${ }^{44}$ Muruwwa. Dirasat fi al-Islam, 10
} 
Muruwwa memiliki catatan yang positif tentang Tauhid, tapi juga kontroversial. Ia menerima pendapat bahwa Tauhid adalah tentang kesadaran agama (ketuhanan). Namun ia menambahkan bahwa Tauhid juga seharusnya tentang kesadaran sosial (kemanusiaan) dan intelektual (budaya baru). Kesadaran ketuhanan adalah tahapan terendah dan harus diangkat menjadi kesadaran kemanusiaan dan akhirnya menjadi budaya baru. ${ }^{45}$ Dengan skema pembacaan ulang menggunakan pendekatan materialisme historis semacam ini, unsur teologis agama mau tidak mau harus dikorbankan demi memunculkan unsur sosial dan intelektualnya. Jika tidak demikian, maka Islam selamanya akan gagal secara sosial dan budaya.

Ini mirip dengan skema yang ditawarkan Hassan Hanafi yang terkenal dengan paradigma "dari akidah menuju revolusi". Akidah ditinggalkan demi mewujudkan revolusi untuk perubahan. ${ }^{46}$ Juga mirip dengan Auguste Comte yang terkenal dengan pandangannya bahwa perkembangan masyarakat hanya bisa dilakukan jika fase teologis dilalui dan ditinggalkan untuk mencapai fase metafisik dan akhirnya positifistik ${ }^{47}$ Yang disebut terakhir ini adalah fase masyarakat moderen yang dicirikan dengan perkembangan ilmu pengetahuan dan pola pikir rasional.

Serupa dengan Comte, Muruwwa merasa bahwa perubahan hanya bisa dilakukan jika masyarakat Islam melalui fase pertama (teologis), lalu bergerak menuju fase kedua (sosial) dan kemudian ketiga (budaya). Menariknya, ia yakin Islam bisa melakukannya karena "Islam dirancang untuk bergerak, dan gerak adalah filosofi dari Tauhid itu sendiri". ${ }^{48}$ Hakikat Tauhid baginya tidak saja menyatukan atau menunggalkan, namun juga bersatu untuk bergerak

${ }^{45}$ Muruwwa. Dirasat fi al-Islam, 18

${ }^{46}$ Terkait pemikiran Hassan Hanafi mengenai hal ini, lihat Hassan Hanafi. 1988. Min al-Akidah ila al-Thaurah (Kairo: al-Markaz al-Thaqafi al-Arabi). Sementara itu Fahmi Jad'an menyerupakan paradigma "dari turath ke revolusi" ala Muruwwa dengan paradigma "dari akidah ke revolusi” ala Hassan Hanafi. Lihat Jad'an. Ibid.

${ }^{47}$ Memang tidak dapat ditemukan bukti bahwa Muruwwa terpengaruh oleh Comte secara langsung. Hanya saja popularitas Comte di dunia Arab terutama di kalangan pemikir liberal dan positifistik sangat menonjol. Yang menarik adalah, para pemikir yang terpengaruh oleh Comte memiliki proyek pemikir yang sama dengan Muruwwa yaitu mengusung konsep budaya baru di dunia Arab. Di antara pemikir Arab yang paling terpengaruh oleh Comte adalah Muhammad Hussain Haikal (w. 1956). Lihat Elizabeth Suzanne Kassab. 2010. Contemporary Arab Thought: Cultural Critique in Comparative Perspective (New York: Columbia University Press), 258

${ }^{48}$ Muruwwa. Dirasat fi al-Islam, 12 
mewujudkan revolusi. Maksudnya, jika secara teologis Tauhid adalah menunggalkan Tuhan, maka secara sosial ia berarti bersatu untuk bergerak, dan secara intelektual berarti bersatu mewujudkan budaya baru lewat ilmu pengetahuan. ${ }^{49}$

Manifestasi Islam yang ia lihat pada masa hidupnya adalah yang berbau teologis. Itu adalah kegagalan. Pemahaman lama atas Tauhid harus dirubah dan dikembangkan. Lagi-lagi Muruwwa membagi masyarakat Islam terkait dengan pemahaman Tauhid menjadi dua, yaitu kelompok lama dan kelompok baru. Yang lama adalah yang menghendaki status quo dan mempertahankan sistem yang berlaku demi mengekalkan kepentingan mereka, dengan alasan agama. Sedang yang kedua menghendaki perubahan dan perkembangan. Penganut paham teologis memiliki kesadaran monotheistikyang kaku. "Gambaran mereka tentang Tuhan terlalu abstrak sehingga tidak mudah ditangkap oleh masyarakat umum".50 Sedang paham kedua mengembangkan kesadaran monotheistik yang lebih kongkret dan ilmiah. Kelompok ini sensitif, peduli dan peka pada masalah sosial dan perubahan zaman.

Kelompok pertama memahami Islam tanpa memperhatikan hubungan antara penafsir sebagai subjek dengan kondisi sosial mereka. ${ }^{51}$ Pemahaman mereka terhadap Islam idealistik dan essential. Terdapat jarak yang jauh antara idealisme mereka dan kenyataan sosial. Agama dalam narasi mereka pasif dan statis. Tauhid religius diseret ke ranah Tauhid politik. Agama ditunggangi untuk kepentingan kekuasaan. Para penguasa didapuk menjadi "tuhan baru" yang harus ditaati secara mutlak. ${ }^{52}$ Kelompok ini tidak mengenal keberagaman. Kebenaran sifatnya tunggal, mutlak dan tanpa tawar. Menurut Muruwwa, masyarakat ini tidak pernah berubah selama tidak mengakui keberagaman. Padahal keberagaman adalah jaminan masyarakat akan bergerak. Selama keberagaman tidak mendapat tempat yang layak, perubahan tidak akan dapat bergerak. ${ }^{53}$

Sementara itu dalam wacana kedua, terdapat hubungan yang dinamis dan dialektis antara penafsir dan objek yang ditafsir. Kelompok ini berusaha

\footnotetext{
${ }^{49}$ Muruwwa. Dirasat fi al-Islam 17-19

50 Muruwwa. Dirasat fi al-Islam..., 12

${ }^{51}$ Muruwwa. Dirasat fi al-Islam...., 42

52 Muruwwa. Dirasat Naqdiyyah, 181

${ }^{53}$ Muruwwa. Dirasat fi al-Islam..., 182
} 
mengaitkan sejarah dengan visi masa depan. Menghadirkan masa lalu dalam konteks masa kini, dan memaknai masa kini dalam terang cahaya masa lalu. ${ }^{54}$ Turath dipahami sebagai kesadaran dan tidak sekedar lembaran kosong tanpa arti. 55

Ini artinya dalam skema penafsiran Muruwwa, agama harus diangkat atau ber-evolusi menjadi sistem sosial dan kemudian budaya. Tentu dengan implikasi mengorbankan sistem keyakinan, sistem peribadatan, dan moralitas dalam agama. Implikasi selanjutnya, menghapus konsep Tuhan, kitab suci, risalah kenabian, dan menghilangkan konsep baik dan buruk.

Hilangnya aspek teologis dari sistem sosial dan budaya merupakan hal yang diharapkan oleh Muruwwa. Sepertinya ia merasa manusia akan lebih bebas dengan dirinya tanpa ada kekuatan lain yang mengaturnya. Demi kemajuan materi Muruwwa tidak keberatan jika dimensi ajaran dan keyakinan dalam agama dihapuskan. Sayangnya itu langsung bertentangan dengan fitrah manusia itu sendiri yang cenderung ingin kembali dan kembali lagi kepada agamanya atau Tuhannya ketika sampai titik jenuh tertentu.

Muruwwa nampak lupa bahwa logika evolusi meniscayakan adanya pergerakan yang terus menerus tanpa henti. Pertanyaannya, jika terus bergerak kemana agama atau masyarakat harus berlabuh setelah selesai dengan fase ketiga yang ia canangkan? Apakah ada fase lain yang lebih tinggi yang harus dikejar? Jika ada, apa itu? Jika tidak ada apakah harus kembali ke tahapan awal dalam skema paradigma berputar?

Muruwwa juga lupa bahwa Islam memiliki jalannya sendiri. Ada kalanya campur tangan manusia tidak diperlukan dalam Islam. Ia adalah agama wahyu, agama langit yang dalam kadar tertentu tidak mengenal logika sejarah. Islam maju dan bergerak menggunakan hukumnya sendiri, tidak tunduk pada hukum sosialisme, kapitalisme atau isme-isme yang lain. Islam memiliki dimensi sosial dan kultural yang fleksible dapat bermain atau dimainkan secara lentur. Di atas itu, ada nilai yang tidak tunduk pada kondisi sosial. Ia bersifat final dan universal. Tidak dapat dilokalisir atau direduksi menjadi tatanan yang sempit. Tauhid adalah nilai itu. Ia adalah landasan kehidupan, dan fitrah yang dengannya

\footnotetext{
${ }^{54}$ Muruwwa. Dirasat fi al-Islam...., 44

55 Muruwwa. Dirasat fi al-Islam....., 46
} 
manusia akan terus mencari Tuhannya. Dengannya manusia akan mencapai derajat kesempurnaannya.

Muruwwa tahu manusia akan terus mengejar kesempurnaannya. Hanya saja standar kesemmpurnaan baginya bukan kesucian fitrah, melainkan "capaian materi karena Islam bukan agama fitrah melainkan agama materialistik sejak kemunculannya di tangan nabi". 56

\section{Tasawuf dan "Tuhan Emanasi”}

Berangkat dari keyakinannya tentang Islam sebagai agama materialistik, ia membangun argumen bahwa segala hal yang terkait dengan agama ini mulai dari kitab sucinya, kerasulan nabinya, sistem ritualnya, paradigmanya, budaya dan tradisinya dibangun di atas pondasi materialisme. Demikianlah antara lain intisari dari pemikiran Muruwwa yang ditemukan oleh Hisham Ghassan Tohme dan Musa Barhumah dalam tesis magisternya masing-masing. 57

Tohme dan Barhumah tidak keliru. Identitas pemikiran Muruwwa memang terang benderang. Bahkan karyanya yang disepakati oleh semua orang sebagai magnum opusnya, ia beri judul al-Naza'at al-Maddiyah fi al-Falsafah alArabiyyah al-Islamiyyah (Trend Materialistik dalam Filsafat Arab-Islam). Dari judulnya sudah terlihat apa yang ingin ia katakan. Terbit pertama kali tahun 1978, karya ini terdiri dari 4 (empat) jilid dengan masing-masing jilid terdiri antara 460 hingga 580 halaman. Jilid pertama berisi pengantar, pembahasan era Jahiliyah, latar belakang kemunculan Islam, dan Islam pada masa Khulafa al-Rashidun. Jilid kedua bicara mengenai al-Mu'tazilah, al-Asy'ariyyah dan Ilmu Mantiq. Jilid ketiga mengupas masalah filsafat, tasawuf dan aliran Ikhwan al-Shafa. Sedang jilid keempat mengangkat pemikiran tiga tokoh yang ia kagumi yaitu al-Kindi, alFarabi dan Ibn Sina.

Oleh pengagumnya, karya ini dianggap sebagai puncak kematangan pemikirannya. Dalam ungkapan Peter Gran, "beberapa tahun setelah terbit, karya ini masih merupakan buah pikiran paling fenomenal dan monumental tentang

56 Hisham Ghassan Tohme. 2012. Mahdi 'Amil and Husayn Muruwwa: Locating Marxism in the Arab Context. Tesis Master, American University of Beirut.

57 Untuk tesis magister Tohme, lihat Hisham Ghassan Tohme. Ibid. Sedang untuk tesis Barhumah, lihat Musa Barhumah. 2007. Al-Turath al-Arabi wa al-'Aql al-Madi: Qira'ah fi Fikr Hussain Muruwwa (Beirut: Dar al-Tanwir) 
pemikiran Islam dari sudut pandang Marxist dan sosialist". 58 Sementara dalam bahasa Yoav Di-Capua, al-Naza'at adalah "karya terlengkap dan paling sistematis mengenai hubungan antara pengentahuan Arab-Islam klasik dengan budaya Arab-Islam kontemporer". Komentar dari penerbit layak dicatat di sini. Setelah menyebut Muruwwa sebagai al-Allamah al-Syahid, penerbit menilai karya ini "telah mengisi kekosongan yang selama ini ditinggalkan oleh para cendikiawan" ${ }^{59}$ Musa Barhumah yang menyebutnya juga sebagai al-Syahid dan menulis tesis magisternya di Universitas Yordania tentang Muruwwa menyebut al-Naza'at sebagai sarana "perjuangan keras dalam konteks gerakan pembebasan di dunia Arab".60 Ada pula yang membandingkannya dengan pemikiran Suhail Idris, yang melihat substansi sejarah pemikiran Arab-Islam sebagai bentuk dari politisasi agama.

Muruwwa sendiri menganggap al-Naza'at sebagai "usaha mengusung dan menggali unsur-unsur progressif dalam khazanah pemikiran Islam".61 Seperti dalam karyanya yang lain ia meluapkan kekecewaannya terhadap para pendahulu yang gagal membangun kerangka ilmu yang memadahi. Sebagaimana ia juga mengkritisi sejawatnya yang tidak mampu mengembangkan turath yang mereka warisi.62

Selama ini -menurutnya- turath didominasi oleh dua trend pemikiran, yaitu metafisika fundamentalis dan idealisme liberal. Kedua trend ini "gagal dalam mengungkapkan hubungan yang objektif dan realis antara bangunan internal pemikiran turath dengan perubahan sosial.63 Penyebabnya, karena keduanya mengabaikan aspek historisitas pemikiran. Ini mengakibatkan turath menjadi subjektif, ahistoris dan secara mendasar tercerabut dari akar sosialnya, yaitu dari sejarahnya yang nyata dan objektif. Sejarah Islam dengan kata lain, pasif dan sulit dikembangkan.

58 Peter Gran. 1987. "Islamic Marxism in Comparative History: The Cause of Lebanon, Reflections on the Recent Book by Husayn Muruwwa”. Dalam The Islamic Impulse. Editor Barbara Stowasser (London: Croom Helom). Lihat juga Steve Tamari. 1995. "Reclaiming the Islamic Heritage: Marxism and Islam in the Thought of Husayn Muruwwa". Dalam Arab Studies Journal 3:1 (Spring, 121-129)

${ }^{59}$ Hussain Muruwwa. 2002. Al-Naza'at al-Madiyyah fi al-Falsafah al-Arabiyah wa al-Islamiyah. Cetakan pertama (Beirut: Dar al-Farabi), 5

${ }^{60}$ Barhumah. Ibid., 13

${ }^{61}$ Al-Safir (September, 24, 1985), 10

62 Muruwwa. Al-Naza'at. Jilid I, 7

63 Muruwwa. Al-Naza'at. Jilid I, 6 
Muruwwa lantas menawarkan cara pandang baru. Katanya, "hanya metode materialisme historis yang mampu menemukan hubungan yang hilang antara turath dan konteks sosialnya, atau secara lebih makro mengungkap pergerakan warisan pemikiran Islam dalam sejarah".64 Ia menyebut cara pandang ini paling ilmiah dan orisinil baik pada tataran teoretis maupun penerapan. Pendekatan lain seperti nasionalisme, Islamisme atau sekularisme ia sebutterlalu romantisis dan tidak berguna. Ia pernah memuji pendekatan historis yang ditawarkan oleh Ibrahim Madkur terutama dalam membaca tasawuf.65 Namun sejurus kemudian ia kecewa karena pendekatan ini nyatanya hanya mampu mendalami sejarah para sufi atau biografi mereka, bukan pengalaman spiritual yang mereka alami dan hubungannya dengan konteks sosialnya.

Materialisme historis yang ia gunakan meniscayakan bahwa perkembangan masyarakat ditentukan dan dipengaruhi oleh adanya hubungan sosial yang nampak dari pola-pola produksi. Dan itu didukung oleh hukum alam dan sosial di mana pergerakan masyarakat selalu mengarah kepada keterpenuhan materialistik, dan -pada puncaknya- keberlimpahan sarana dan fasilitas hidup. Kemajuan masyarakat dari satu fase ke fase lain ditentukan oleh ketersediaan sarana ini. Adanya masyarakat secara otomatis membentuk polapola hubungan antar sesama anggotanya didorong oleh faktor kebutuhan untuk bertahan hidup. Pola hubungan terus berkembang mulai dari fase primitif, ke fase perbudakan, hubungan pekerja, kapitalisme, dan berakhir dalam bentuknyayang paling sempurna yaitu Marxisme ilmiah. ${ }^{66}$

Jadi, jika dibaca menggunakan pendekatan ini maka sejarah Islam adalah tentang perjuangan bertahan hidup dengan pola hubungan tertentu, demi meraih kesempurnaan duniawi. Ini berlaku untuk semua agama dan semua dimensinya termasuk tasawuf. Dalam konteks ini, tasawuf dipahami sebagai seni bertahan hidup dengan pola hubungan spiritual antar sesama.

${ }^{64}$ Muruwwa. Al-Naza'at. Jilid I...., 8

${ }^{65}$ Muruwwa. Al-Naza'at. Jilid I...., 106

${ }^{66}$ Dalam bentuknya yang paling mutakhir setelah mengalami banyak perdebatan, Marxisme ilmiah diartikan sebagai "pengetahuan tentang realitas". Dalam kerangka ini, hakekat masyarakat lebih dipahami sebagai enitas yang melibatkan adanya hubungan antar manusia, tidak lagi antar benda. Materialisme tidak selamanya berarti kebendaan, melainkan bergeser menjadi kemanusiaan. Memang persoalannya, Marxisme tidak memahami manusia sebagai ruh dan jiwa, melainkan sebatas raga. 
Muruwwa memiliki perhatian khusus kepada tasawuf. Setidaknya dua kali ia membahasnya dalam dua karya yang berbeda. Pertama pada bagian akhir Turathuna, dan kedua pada jilid ketiga al-Naz'ah al-Maddiyah. Dalam Turathuna, ia mengingatkan bahwa, "bicara mengenai Tasawuf harus dilakukan dalam konteks sejarah. Jika tidak, maka itu salah". ${ }^{67}$ Ia menambahkan, "Tasawuf harus dibaca secara realistis, dan bukan abstrak-mutlak". 68

Membaca tasawuf secara realistis berarti bahwa tasawuf diperlakukan sebagai fenomena sosial dan kenyataan sejarah, bukan semata sebagai pemikiran murni atau bagian dari ajaran agama. Lagi pula, secara medasar Muruwwa memisahkan tasawuf dari Islam. Baginya, tasawuf adalah produk dari pola hubungan timbal balik antar manusia dalam masyarakat. Ia hadir dalam ruang yang kongkret. Maksudnya, "tasawuf lahir dari proses interaksi yang dimanis antara indifidu manusia dengan masyarakatnya, atau antara kesadaran manusia dengan kegiatan sosialnya di dalam masyarakat. Atau bisa juga lahir dari hubungan saling mempengaruhi antara bentuk-bentuk interaksi sosial yang ada dalam masyarakat dengan kesadaran manusia, atau interaksi antara hukumhukum dunia materialistis dengan hukum-hukum pemikiran dalam konteks kegiatan spiritual manusia".69

Dengan ungkapan ini, Muruwwa ingin mengatakan bahwa Tasawuf tidak ada hubungannya dengan Islam. Ia tidak lahir dari agama manapun, atau diibentuk oleh tradisi apapun. Pendapat yang selama ini berkembang bahwa Tasawuf berasal dari Islam, atau dari sumber lain di luar Islam seperti budaya Persia, India, tradisi Yahudi dan Kristem, ia tolak. ${ }^{70}$ la memandang keliru kedua anggapan itu karena tidak sesuai dengan logika sejarah dan melupakan unsur paling penting yang membentuk setiap kegiatan dan bahkan kesadaran manusia, yaitu unsur sosial, politik dan ekonomi.

Menggunakan skema evolutif ala Ausguste Comte, Muruwwa berpandangan bahwa masyarakat yang membentuk tasawuf pada periode awal kemunculannya (hinnga abad 2 Hihriyah) adalah masyarakat teologis. Nuansa sosial dan ilmiah belum muncul pada fase ini. Karena itu, Tasawuf belum memiliki kesadaran sosial atau intelektual. Ajarannya fokus pada kesadaran ketuhanan -

\footnotetext{
67 Muruwwa. Turathuna, 351

${ }^{68}$ Muruwwa. Turathuna, 351

${ }^{69}$ Muruwwa. Al-Naza'at. Jilid III, 46

${ }^{70}$ Muruwwa. Al-Naza'at. Jilid III...., 44-46
} 
hubungan antara Tuhan dan manusia- melalui konsep "menarik diri dari urusan sosial" atau yang lebih populer dengan sebutan kezuhudan.

Kezuhudan sendiri adalah ajaran paling awal yang dikembangkan oleh para sufi. Sebagai cikal bakal dari tasawuf, ia bahkan sudah ada dalam bentuknya yang belum sistematis sebelum tasawuf itu sendiri lahir. Gagasan ini berkembang dari masa ke masa. Pada periode awal dapat ditemukan dari ajaran Amir b. Abd Qais dan Hasan al-Basri yang mengajarkannya sebagai manifestasi dari rasa takut akan siksa Tuhan, dan menjaga jarak dari kehidupan duniawi. Kuzuhudan tidak sekedar dalam artian a) mengambil yang halal dan menghindari yang haram, atau b) menyisakan yang lebih dan memberikannya kepada yang membutuhkan. Namun juga dalam artian menghindar dari kesenangan duniawi demi kebahagiaan akhirat.

Kesadaran ketuhanan yang ekstrem seperti ini membuat para sufi tidak saja kehilangan kesadaran sosial, namun juga tidak memiliki kemampuan berinteraksi dengan sesama. Mereka adalah manusia tertutup. Contoh lain yang diambil Muruwah tentang kezuhudan ekstrem adalah Abdul Aziz al-Rosibi yang dalam Hilyah al-Awliyah dikisahkan tidak pernah keluar rumah. ${ }^{71}$ Mereka juga terserap terlalu jauh ke dalam ritual.

Dari konsep kezuhudan ini kemudian lahir ajaran tentang cinta ilahi, wahdatul wujud, hulul dan ittihad. ${ }^{72}$ Konsep cinta ilahi diciptakan oleh Rabi'ah alAdawiyah (w. 801) dan didukung oleh para sufi Basrah awal seperti Khalid b. Abdullah, Atabah al-Ghulam dan Habib al-Farisi. Ibrahim b Adham (w. 777), Abdullah b. al-Mubarak (w. 797) dan Shaqiq al-Balkhi (w. 809) juga merupakan pelaku kezuhudan yang memiliki kecenderungan cinta ilahi.

Pada perkembangan berikutnya, di tangan Ma'ruf al-Karkhi (w. 815) kezuhudan bersentuhan dengan konsep makrifat melalui penyingkapan (alKasyf), penyaksian (al-Musyahadah), penyinaran (al-Isyraq). ${ }^{73}$ Praktik dari itu semua adalah al-Mujahadah atau al-Riyadhah. Dari sini lahir tarekat, seni mengendalikan diri dari godaan gemerlapnya kehidupan duniawi. Al-Karkhi

\footnotetext{
${ }^{71}$ Muruwwa. Al-Naza'at. Jilid III, 73

72 Muruwwa. Al-Naza'at. Jilid III., 74

${ }^{73}$ Muruwwa. Al-Naza'at. Jilid III., 91
} 
sendiri mengartikan makrifat sebagai, "mengambil perkara yang hakekat dan meninggalkan apa-apa yang ada di tangan makhluq". ${ }^{74}$

Al-Karkhi menandai berakhirnya fase tasawuf teologis dan mengantarkannya memasuki fase kedua, yaitu sosial. Masuknya konsep zahir dan batin sebagai model penafsiran atas makna kezuhudan pada abad ketiga Hijriyah atau sembilan Miladiyah ia anggap sebagai titik balik dari tasawuf. Pada tahap ini, lahir Daud al-Tha'i (w. 781) dan al-Fudhail b. Iyadh (w. 802). Al-Tha'i selalu bersosial dan gemar bertemu dengan kalangan lemah. Demikian pula dengan al-Fudhail. 75

Al-Tha'i sendiri tidak memiliki karya, namun perjuangan sosialnya memang sangat melegenda. Ia lebih memilih hidup serba kekurangan bukan saja untuk mendekatkan diri kepada Tuhan melainkan juga demi membela kaum miskin. Kisah keteladanannya antara lain diungkap oleh Fariduddin Attar dalam Tazkiratul Auliya. Dalam Siyar 'Alam al-Nubala disebutkan al-Tha'i sebagai "seorang ilmuan dan ahli fikih, tauladan dan zahid".76 Sementara al-Fudhail diakui secara luas sebagai sosok sufi yang memiliki pengaruh yang luas. Namanya disebut dengan hormat oleh Abu Abdul Rahman al-Sulami dalam Thabaqat alSufiyah juga oleh al-Qushairi dalam al-Risalah.

Pengamatan Muruwwa bahwa kedua tokoh sufi itu sebagai sufi sosial tidak terlalu salah, namun juga tidak selamanya benar. Al-Tha'i umpama mengajarkan "larilah dari manusia seperti engkau lari dari singa". Ia juga mengajarkan "puasalah engkau sepanjang hidupmu dan jangan engkau meninggalkan puasa hingga kematian menjemputmu". Sementara al-Fudail terkenal dengan kezuhudannya. Ia sangat takut dengan hari kiamat sehingga ia pernah mengatakan, "jika aku dikasih pilihan antara menjadi anjing dan melihat hari kiamat, maka aku akan memilih menjadi anjing dan mati sebagai anjing". ${ }^{77}$

${ }^{74}$ Abu al-Qasim Abdul Karim. 2010. Al-Risalah Qushairiyah (Beirut: Dar al-Kutub alIlmiyah), 149

75 Abu al-Faraj Abdul Rahman Ibn al-Jauzi. 1968. Sofwah al-Sofwah. Juz III (Kairo: Dairah al-Ma'arif al-Ilmiyah), 65

76 Muhammad b. Ahmad al-Zahabi. 1982. Siyar 'Alam al-Nubala. Jilid 7 (Kairo: Mu'assasah al-Risalah), 423

${ }_{77}$ Abu Na'im al-Isfahani. Hilyah al-Awliya wa Thobaqot al-Asfiya. Juz VIII (Beirut: Dar al-Kutub al-Ilmiyah), 84. Lihat juga Abu Abdul Rahman al-Sullami. Thobaqot al-Sufiyah. 2003 (Kairo: Dar al-Kutub al-Ilmiyah), 22, 27 
Pada tahap berikutnya yaitu tahap akhir, tasawuf berubah menjadi gerakan filosofis dengan misi ideologis. Inilah transformasi terbesar yang pernah terjadi pada tasawuf. Muruwwa menetapkan perubahan ini terjadi pada abad ketiga Hijriyah -seperti dari tahap pertama ke tahap kedua- bersamaan dengan terjadinya transformasi politik dalam tubuh Khilafah Abbasiyah. Secara politik, abad ini -dan berlanjut hingga abad keempat Hijriyah- termasuk masa yang paling kritis dalam sejarah Islam. Ini adalah fase dinamis yang mempengaruhi wajah peradaban Islam di kemudian hari. Diawali pada tahun 749 hingga tahun 847 Miladiyah, fase ini dikenal dengan era pertama dan kedua Khilafah Abbasiyah, atau dari Khalifah al-Wathiq hingga al-Mutawakkil.

Perubahan besar yang dimaksud Muruwwa yang terjadi pada fase ini antara lain, 1) bergesernya sentimen politik dari keluarga Bani Umayah ke Bani Abbasiyah, dan 2) munculnya ideologi politik beraliran teokratis yang memanfaatkan nasab kenabian sebagai legitimasi untuk memaksa rakyat patuh dan tunduk secara mutlak kepada pemimpin. ${ }^{78}$ Sifat teokratis kekhalifahan Abbasiyah antara lain terlihat dari pidato Khalifah Abu Ja'far al-Mansur di Mekkah saat ia mengatakan, "wahai sekalian manusia, sesungguhnya saya adalah wakil Tuhan di muka bumi. Saya memerintah kaliah dengan persetujuan, dukungan, dan izin-Nya. Saya juga penjaga atas harta kekayaan-Nya. Saya bekerja menjaganya atas kehendak dan kemauan-Nya, dan membagi harta atas izinNya".79

Muruwwa menyebut ideologi semacam ini "berbasis Syariah". Negara bersifat absolutis. Hubungnnya dengan masyarakat didasar atas keabsolutannya. Sebagai wakil Tuhan di muka bumi dengan sifat keabsolutannya, penguasa bertindak otoriter dan terjauhkan dari rakyat. Mereka memerintah atas dasar bahwa itu adalah "kehendak Tuhan". Ketidakadilan diatasnamakan agama. ${ }^{80}$ Dengan Khilafah dicitrakan sebagai representasi agama, ia memiliki hak mutlak untuk mengatur dan menentukan pemikiran orang dan bagaimana mereka harus hidup dan bertindak. ${ }^{81}$ Muruwwa mencatat, sistem kekuasaan di Baghdad sangatlah paradox. Pada satu sisi mereka mengaku sebagai wakil Tuhan, namun sisi lain mereka adalah kelas borguis yang berkuasa demi meraih

\footnotetext{
78 Muruwwa. Al-Naz'at. 98

${ }^{79}$ Muruwwa. Al-Naz'at...., 98

${ }^{80}$ Muruwwa. Al-Naz'at..... 106

81 Muruwwa. Al-Naz'at....., 107
} 
keuntungan materi dan ekonomi. Satu sisi mencitrakan diri sebagai imam dan pemuka agama, sisi lain mereka serakah. ${ }^{82}$

Dalam konteks seperti inilah tasawuf berubah menjadi filosofis setelah sebelumnya melalui fase teologis dan sosial. Pada tahap ini tasawuf tidak lagi berisi ajaran metafisis yang abstrak, namun sudah menjadi sistem pemikiran oposisional kepada dua hal, yaitu kepada agama dengan menawarkan takwil, dan kepada politik dengan menolak segala bentuk kezaliman.83 Dengan ungkapan lain dalam bentuk filosofisnya, tasawuf -menurut Muruwwa- adalah gerakan pemikiran sistematis untuk menolak Islam dan sistem politik teokratis pada saat yang bersamaan. Inilah kerangka teoretis yang ia gunakan untuk membaca keseluruhan warisan pemikiran tasawuf terutama yang bernuansa filosofis.

Dalam al-Naza'at ia membahas tasawuf dengan sangat serius. Argumennya berat. Pembaca akan kelelahan dibuatnya. Bagi yang tidak memiliki latar belakang filsafat akan cepat bosan. Dalam karya ini tasawuf dibahas pada jilid ketiga bab kedua. Bab pertama membahas filsafat, sedang bab ketiga mengupas Ikhwan al-Shofa. Pembahasan mengenai tasawuf cukup panjang mulai dari halaman 43 hingga 268, atau 225 halaman.

Secara umum, pembahasannya mengenai tasawuf dibagi menjadi tiga bagian besar. Pertama tentang fenomena kezuhudan dan latar belakang sosialpolitik yang memicu kemunculannya. Ini adalah fase tasawuf teologis. Kedua membahas tentang ideologi tasawuf teoretis, atau tasawuf pada fase sosial. Dan ketiga, tentang tasawuf filosofis atau fase terakhir.

Tasawuf filosofis sendiri sangat luas, dan definisinya masih menjadi perdebatan. Muruwwa sendiri tidak bicara tentang pengertian. Namun pemikirannya tentang jenis tasawuf ini mengarah kepada sosok-sosok sufi yang secara umum sudah diketahui sebagai sufi filosofis seperti al-Hallaj, Yahya Suhrwardi dan Ibn Arabi. Dua nama terakhir menjadi fokus paling utama dalam pembahasannya. Konsep iluminasi (Ishraqiyyah) Surhawardi, dan wahdatul wujud serta insan kamil Ibn Arabi ia bahas secara panjang lebar. Menurutnya, ketiga gagasan ini merupakan kepanjangan tangan dari konsep emanasi yang dikembangkan al-Farabi, al-Kindi dan Ibn Sina. Ketiga konsep ini mencerminkan kematangan puncak tasawuf filosofis. Pada ketiganya dapat ditemukan potret

\footnotetext{
82 Muruwwa. Al-Naz'at....., 103

${ }^{83}$ Muruwwa. Al-Naz'at...... 65
} 
pemikiran tasawuf yang sesungguhnya yang mengandung unsur perlawanan terhadap kemapanan agama dan politik.

Muruwwa menafsirkan gagasan emanatif ini dari sudut pandang materialistik yang revolusioner. Ia menghasilkan kesimpulan bahwa konsep ini tidak saja bicara tentang hubungan antara manusia dan Tuhan, melainkan juga tentang kemampuan manusia untuk naik derajat menjadi imam, nabi bahkan Tuhan.84 Manusia adalah "insan kamil" yang memiliki segala potensi untuk membuat langkah raksasa menentang segala bentuk angkara-murka. Dalam ungkapan Muruwwa, melalui gagasan mereka para sufi menawarkan "Tuhan emanasi" sebagai lawan dari "Tuhan teokrasi". Tuhan teokrasi adalah para pemimpin politik yang otoriter, sedang Tuhan emanasi adalah para sufi sendiri.

Yang membuat hati berdebar adalah ketika Muruwwa berujar bahwa pemikiran Islam harus berani keluar dari kerangka Tauhid agar dapat berfungsi secara sosial dan menunjukkan karakter filosofisnya. Dalam konteks ini, ia membedakan tiga jenis pemikiran Islam, yaitu pemikiran metafisis, filosofis dan ideologis. Jenis pertama menurutnya tidak pernah berani keluar dari kerangka Tauhid. Namun jenis kedua dan ketiga -tasawuf termasuk di dalamnya- tidak demikian. ${ }^{85}$ Tasawuf filosofis umumnya bersifat ideologis dan sudah lama meninggalkan Islam menjadi sebuah ideologi perlawanan. Inti dari ajaran tasawuf jenis ini, menurutnya adalah "menjadikan manusia sebagai Tuhan". 86

\section{Kesimpulan}

Setiap kelas memiliki ideologi dan setiap ideologi menciptakan pengetahuannya sendiri. Itulah kira-kira salah satu kesimpulan yang bisa ditarik dari pemikiran Husain Muruwwa. Kalimat itu menggambarkan dirinya sebagai indifidu sekaligus mencerminkan prinisip yang ia pedomani dalam karir akademiknya. Tak ayal ia merasa "bebas" berwacana tanpa dibatasi oleh apapun termasuk agama.

Sebagai prinsip, pedoman itu membuatnya mamandang ilmu seperti tasawuf sebagai ideologi tercerabut dari sumbernya, yaitu Islam. Ini pembacaan yang tidak biasa. Jutaan lembar yang pernah ditulis oleh para sufi di setiap masa

\footnotetext{
${ }^{84}$ Muruwwa. Al-Naz'at...., 171

85 Muruwwa. Al-Naz'at......, 179

86 Muruwwa. Al-Naz'at....., 185
} 
menunjukkan bahwa wacana dan ajaran mereka nyaris selalu berlandaskan pada pemahaman atas agama. Pengaruh sosial tetap ada dalam tasawuf. Namun itu adalah faktor, bukan sumber.

Gagasan bahwa tasawuf adalah ideologi membawa implikasi yang tidak sedikit. Pertama, itu menafikan aspek epistemologis ilmu ini. Walau Muruwwa mengakui tasawuf sebagai filsafat, namun pada akhirnya yang ia maksud dengan filsafat adalah ideologi itu sendiri bukan bangunan ilmu pengetahuan.

Kedua, itu juga berdampak pada identitas para sufi. Dengan mengatakan demikian berarti para sufi dianggap sebagai ideolog. Kenyataannya tidak demikian. Betapa banyak pelaku tasawuf yang tidak tahu menahu soal ideologi atau tidak peduli dengan ideologi. Lagi pula era ideologi sudah selesai, dan tasawuf tidak mati bersamaan dengan matinya ideologi.

Ketiga, jika tasawuf adalah ideologi bagaimana dengan tarekat? Muruwwa tidak pernah bicara soal ini. Dan itu sudah cukup sebagai bukti akan kegagalan wacananya.

Namun demikian, Muruwwa tetap dapat dianggap telah memberi kontribusi tersendiri dalam kajian pemikiran keislaman dan tasawuf. Cara bacanya atas turath mengingatkan kita akan, a) pentingnya menguasai warisan pemikiran secara utuh dengan cara yang benar walau cara dia sendiri belum tentu benar, dan b) pentingnya memanfaatkan turath sebagai modal untuk menciptakan wacana atau paradigma baru.

Muruwwa benar bahwa sejauh ini pembacaan atas turath didominasi oleh tiga trend, yaitu a) pemikiran metafisis (ghaibi), b) pemikiran idealistis, dan c) pemikiran deterministis. Semuanya ia anggap lemah dalam hal membuka ruang atau akses untuk kemunculan paradigma baru. Karena itu cara baru harus terus digalakkan walau cara itu tidak harus materialisme historis atau yang serupa dengannya.

Dalam konteks kajian kritis, sementara ini sudah banyak model yang ditawarkan dalam membaca turath. Kaum Marxist seperti Muruwwa, Hadi alAlawi, Abdul Mun'im Khallaf dan Mahmud Ismail menawarkan pendekatan materialisme historis. Abdul Rahman Badawi menawarkan pendekatan 
existensialisme dan humanisme.87 Maxime Rodinson mengusung pendekatan kapitalisme. Bahkan ada yang sangat unik dengan memperkenalkan pendekatan Saxon-Islam seperti yang dilakukan oleh Muhammad Abdul Aziz al-Hababi. ${ }^{88}$

Masih banyak lagi pendekatan lain yang terus bermunculan. Dari kalangan salafi, reformis, modernis, konservatif dan lainnnya juga memiliki pendekatannya sendiri. Apa yang dilakukan oleh Muruwwa terhadap turath jelas menambah warna tersendiri dalam kajian pemikiran Islam. Namun pendekatan epistemologis yang digagas oleh Muhammad Abid Jabiri berikut gagasan cemerlangnya dalam kadar tertentu telah membuat Muruwwa ibarat "harimau tak bertaring". Demikian antara lain hasil penelitian yang dilakukan oleh Josseph A. Massad. ${ }^{89}$

\section{DAFTAR PUSTAKA}

Abisaab, Rula Jurdi dan Malek Abisaab. 2014. The Shi'ites of Lebanon: Modernism, Communism and Hizbullah's Islamists (Syracuse: Syracuse University Press)

al-Alim, Mahmud Amin dan Abdul Azim Anis. 1989. Fi al-Thaqafah al-Misriyah (Kairo: Dar al-Thaqafah al-Jadidah)

Allday, Louis. "Rembering Hussayn Muruwwa: The Red Mujtahid”. Dalam Jadaliyah, 17/2/2017

Anwar, Abdul Malik. 2006. Al-Wathaniyyah Hiya al-Hal (Kairo: Maktabah alShuruq al-Dauliyah).

${ }^{87}$ Abdul Rahman Badawi. 1947. Al-Insaniyyah wa al-Wujudiyyah fi al-Fikr al-Arabi (Kairo: Dar al-Ma'arif).

${ }^{88}$ Muhammad Abdul Aziz al-Hababi. 1969. Al-Shakhsoniyyah al-Islamiyah (Kairo: Dar al-Ma'arif)

${ }^{89}$ Joseph A. Massad. 2007. Desiring Arabs (Chicago: University of Chicago Press), 19 
Badawi, Abdul Rahman. 1947. Al-Insaniyyah wa al-Wujudiyyah fi al-Fikr al-Arabi (Kairo: Dar al-Ma'arif)

Barhumah, Musa. 2007. Al-Turath al-Arabi wa al-Aql al-Madi: Qira'ah fi Fikr Hussain Muruwwa (Beirut: Dar al-Tanwir)

Chalabi, Tamara. 2006. The Shi'is of Jabal Amil and the New Lebanon: Community and Nation-State, 1918-1943 (New York: Palgrave MacMillan)

Di-Capua, Yoav. 2013. "Homeward Bound: Husayn Muruwwah's Integrative Quest for Authenticity". Dalam Jounral of Arabic Literature. I January, Vol 44, Issue 1.

Ende, Werner. 1997. "From Revolt to Resignation: The Life of Mushin Shararah". Dalam Humanism, Culture and Language in the Near East: Studies in Honor of Georg Krotkoff. Editor Asma Asfaruddin dan Mathias Zahniser (Winona Lake: Eisenbrauns)

Gran, Peter. 1987. "Islamic Marxism in Comparative History: The Cause of Lebanon, Reflections on the Recent Book by Husayn Muruwwa". Dalam The Islamic Impulse. Editor Barbara Stowasser (London: Croom Helom)

al-Hababi, Muhammad Abdul Aziz. 1969. Al-Shakhsoniyyah al-Islamiyah (Kairo: Daral-Ma'arif)

Hanafi, Hassan. 1988. Min al-Akidah ila al-Thaurah (Kairo: al-Markaz al-Thaqafi al-Arabi)

Ibn al-Jauzi, Abu al-Faraj Abdul Rahman. 1968. Sofwah al-Sofwah. Juz III (Kairo: Dairah al-Ma'arif al-Ilmiyah)

al-Isfahani,Abu Na'im. Hilyah al-Awliya wa Thobaqotal-Asfiya.Juz VIII (Beirut: Dar al-Kutub al-Ilmiyah)

Jad'an, Fahmi. 2017. "Pengantar". Dalam al-Turath al-Arabi wa al-'Aql alMadi:Qira'ah fi Fikr Hussain Muruwwa (Beirut: Dar al-Tanwir)

Kassab, Elizabeth Suzanne. 2010. Contemporary Arab Thought: Cultural Critique in Comparative Perspective (New York: Columbia University Press)

Khaduri, Madjid. 1978. Socialist Iraqi: Study in Iraqi Politics Since 1968 (London: Middle East Institute) 
Lukitz, Liora. 1996. Iraq: The Search for National Identity (London: Frank Cass)

Majalah Al-Ifran. Nopember 1928, 411

Majalah Al-Safir . 22 September, 1985

Marks, Laura U. 2015. Hanan al-Cinema: Affections for the Moving Image (USA: MIT Press)

Massad, Joseph A.. 2007. Desiring Arabs (Chicago: University of Chicago Press)

Muruwwa, Husain. 1965. Qadaya Adabiyyah (Kairo: Dar al-Fikr)

---- 1984. “Min Najaf Dakhala Hayati Marx”. Dalam al-Tariq. 42: 2-3. June

---- 1984. “Min Najaf Dakhala Hayati Marx". Dalam al-Tariq. 42: 2-3. June 177

---- 1985. Turathuna: Kaifa Na'rifuhu (Lebanon: Mu'assasah al-Abhath alArabiyah)

---- dkk. 1987. Dirasatfi al-Islam (Beirut: al-Farabi)

---- 1988. Dirasat Naqdiyyah fi Dhau al-Manhajal-Waqi'i (Beirut: Maktabah alMa'arif).

--- 1989 "Pengantar". Dalam Fi al-Thaqafah al-Misriyah (Kairo: Dar alThaqafah al-Jadidah)

--- $\quad$ 1990. Wulidtu Shaikhan wa Amutu Tiflan. Editor Abbas Baidun (lebanon: Dar al-Farabi)

---- 1993. Dirasah fial-Fikr wa al-Adab (Beirut: Dar al-Farabi)

---- 1997. "Min Najaf Dakhala Hayati Marx". Dalam Husain Muruwwa Fi Masiratihi al-Nidhaliyyah Fikran wa Mumarasatan. Editor al-Majlis alThaqafi li Lubnan al-Janub (Beirut: Dar al-Farabi)

---- 2002. Al-Naza'at al-Madiyyah fi al-Falsafah al-Arabiyah wa al-Islamiyah. Cetakan pertama (Beirut: Dar al-Farabi)

al-Qushairi, Abu al-Qasim Abdul Karim. 2010.Al-Risalah al-Qushairiyah (Beirut: Dar al-Kutub al-Ilmiyah)

al-Sullami, Abu Abdul Rahman. Thobaqotal-Sufiyah. 2003 (Kairo: Dar al-Kutub alIlmiyah) 
Tamari, Steve. 1995. "Reclaiming the Islamic Heritage: Marxism and Islam in the Thought of Husayn Muruwwa". Dalam Arab Studies Journal 3:1 (Spring, 121-129)

Tohme, Hisham Ghassan. 2012. Mahdi 'Amil and Husayn Muruwwa: Locating Marxism in the Arab Context. Tesis Master, American University of Beirut

Zachs, Fruma. "Cultural and Conceptual Contributions of Beiruti Merchants to the Nahda". Dalam Journal of the Economic and Social History of the Orient. 55 (2012)

al-Zahabi, Muhammad b. Ahmad. 1982. Siyar 'Alam al-Nubala. Jilid 7 (Kairo: Mu'assasah al-Risalah) 
